\title{
A 2500-Year Record of Marine Resource Use on Ulong Island, Republic of Palau
}

\author{
RINTARO ONO ${ }^{a *}$ AND GEOFFREY CLARK ${ }^{b}$ \\ a Department of Marine Civilization, School of Marine Science and Technology, Tokai University, \\ Tokyo, Japan \\ b Department of Archaeology and Natural History, College of Asia and the Pacific, Australian National \\ University, Canberra, Australia
}

\begin{abstract}
The paper reports fish bone and shellfish assemblages from Ulong Island in the Rock Islands of Palau, western Micronesia dating from $\sim 3100$ to $500 \mathrm{BP}$. Use of marine resources in early prehistory appears to have been highly localised with increasing capture of outer-reef/pelagic taxa including shark and tuna after $1000 \mathrm{BP}$. Local stocks of large Tridacnids were depleted during initial human use of Ulong Island, and there is a size decrease in Scarus sp. remains consistent with pressure on the inshore fishery, especially after establishment of permanent stonework villages in late prehistory. Comparison of archaeological assemblages of fish bone from other Rock Islands dated to after 2000 BP indicate that the captured fish species and major capture methods differ between sites and likely reflect local marine environments at each location. Copyright (c) 2010 John Wiley \& Sons, Ltd.
\end{abstract}

Key words: prehistoric fishing; shell analysis; Palau; Ulong Island; Micronesia

\section{Introduction}

Archaeological investigations in Oceania demonstrate that fish and other marine resources were utilised by Pacific Islanders through prehistory. In western Micronesia, human colonisation is generally agreed to be archaeologically visible in the Mariana Islands by 3500 cal. BP (Butler, 1994), with redating of deposits and critical reviews of radiocarbon results pointing to human arrival in Palau and the Marianas by 3400 3100 cal. BP (Fitzpatrick, 2003; Clark, 2004, 2005; Liston, 2005, Clark et al., 2010). There has been no detailed study of early marine resource use in western Micronesia prior to $2000 \mathrm{BP}$, primarily because of an absence of early archaeological sites with sufficient quantities of fish and other marine taxa remains. Of the two major studies of archaeological fish remains from Palau, that of Masse $(1986,1989)$ focused on the period after 1350 BP, while Fitzpatrick \& Kataoka (2005) examined fish bone dating from 2000 to $1250 \mathrm{BP}$ on Orrak Island, with smaller assemblages analysed in limited detail by several researchers (e.g. Osborne,

\footnotetext{
* Correspondence to: Department of Marine Civilization, School of Marine Science and Technology, Tokai University, Tokyo, Japan.

e-mail: rintaro@tokai-u.jp
}

1979; Beardsley, 1997; O'Day, 1997; Clark, 2005; Wright, 2005).

A synthesis of existing records of marine exploitation in Palau to understand long-term changes to the marine ecosystem is hampered by variability in the recovery techniques employed and the limited temporal span of current fish assemblages (see Fitzpatrick \& Kataoka, 2005: 1 and Masse et al., 2006). For instance, the majority of investigations are at sites dating to the last millennium and $6 \mathrm{~mm}$ mesh was used to recover the fish remains. It is known that $6 \mathrm{~mm}$ mesh can under-estimate some faunal classes (e.g. Gordon, 1993; Nagaoka, 1994, 2005; Allen, 2002), but there has been no study comparing the influence of different screen size on faunal remains from Palau. In this paper, we present detailed fish bone and marine shell data from excavation units on Ulong Island with cultural deposits dating to $\sim 3000$ $500 \mathrm{cal}$. BP that were processed using 6 and $3 \mathrm{~mm}$ mesh. Results indicate that use of marine resources in early prehistory was localised with increasing capture of outer-reef/pelagic taxa at 1000-500 BP. There is a size decrease in Scarus sp. remains over time consistent with pressure on the inshore fishery surrounding the small island, particularly once a permanent settlement was established in late prehistory. 


\section{The Palau group and Ulong Island}

The Palau Group is located approximately $7^{\circ}$ north of the equator in western Micronesia some $600 \mathrm{~km}$ distance from Philippines to the west and New Guinea to the south (Figure 1). The archipelago comprises several hundred islands, most of which are small, tectonically uplifted coral reefs referred to locally as 'Rock Islands'. The largest landmass is Babeldaob $\left(367 \mathrm{~km}^{2}\right)$ - the remnant of an eroded volcanic ridge-with volcaniclimestone islands (Koror and Malakal) near to the main island, and two reef platform islands in the south (Peleliu and Angaur). The uplifted karstic Rock Islands, are characterised by a steep and rugged topography, long coastlines, shallow, infertile soils and they have no perennial sources of fresh water (Corwin et al., 1956). The Rock Islands are surrounded, however, by abundant marine resources within an extensive lagoon enclosed

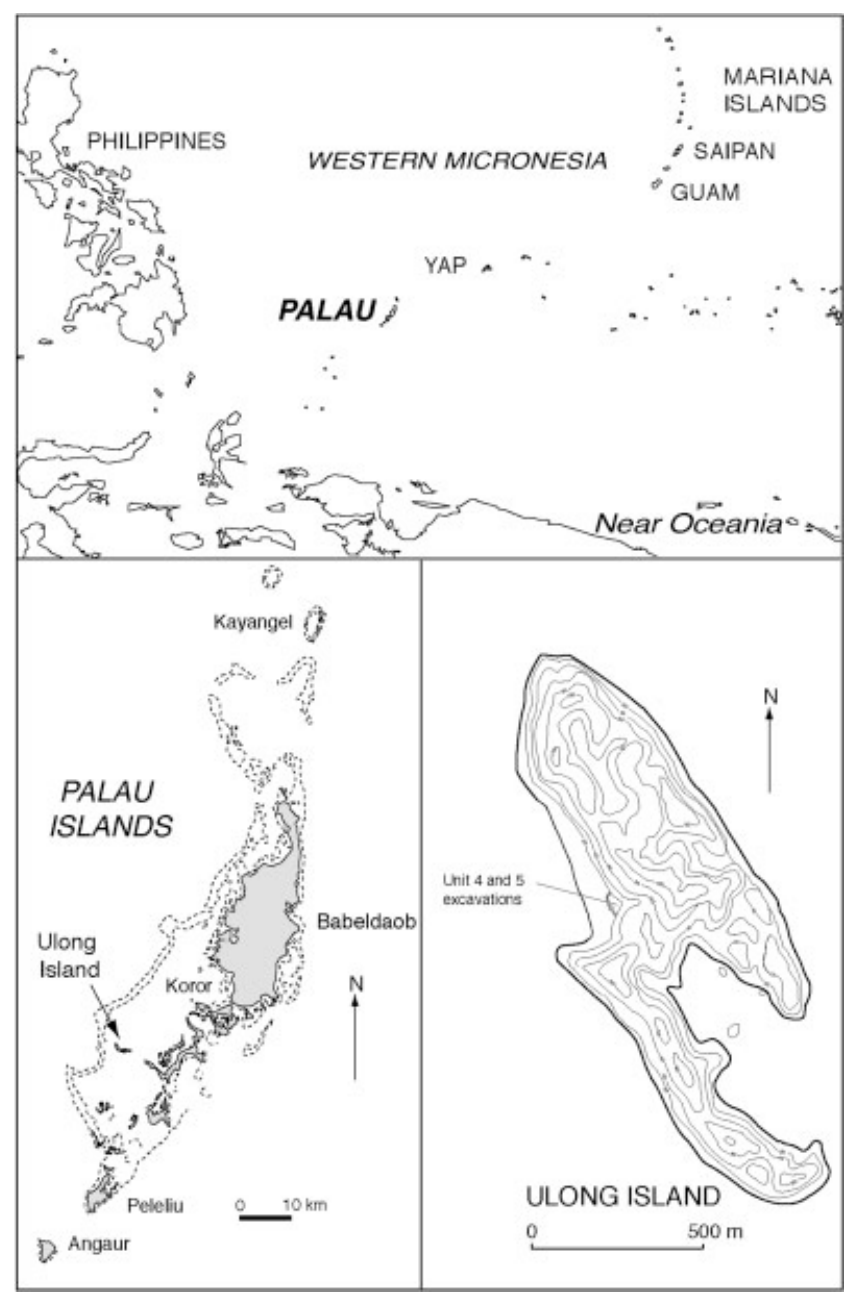

Figure 1. Western Micronesia, Palau and the location of Units 4 and 5 on Ulong Island. by a barrier reef, which holds one of the most diverse marine faunas in Micronesia (Fitzpatrick et al., 2008). The Ulong Group consists of several small limestone Rock Islands, the largest and northernmost is known as Ulong, situated $27 \mathrm{~km}$ southwest of Babeldaob (Figure 1).

Prehistoric remains on Ulong are concentrated on a large beach flat, and were first excavated by Douglas Osborne (1966, 1979) in 1954 and 1969. Osborne examined an area called Aulong 1 Wall Test, which is now registered as the traditional stonework village site B:OR-15-5 (Snyder \& Butler, 1989). Excavation of a $1.5 \mathrm{~m}$ by $4.6 \mathrm{~m}$ trench behind a section of prehistoric limestone wall in 1969 recovered pottery and midden to $1.3 \mathrm{~m}$ depth, but no reliable radiocarbon dates were obtained (Anderson et al., 2005). In 2002, Clark and Wright excavated three units behind the late-prehistoric defensive wall and identified an early cultural deposit dating to 3100-3000 cal. BP. In 2003, another two $1 \mathrm{~m} \times 1 \mathrm{~m}$ test units (Units 4 and 5) were excavated to sample this deposit in greater detail (Wright, 2005; Clark et al., 2006). Unit 4 was $3 \mathrm{~m}$ from the limestone slope and $8 \mathrm{~m}$ south of Unit 5 (Figure 2). The units were excavated in $10 \mathrm{~cm}$ levels and the entire Unit 4 deposit was water sieved over $3 \mathrm{~mm}$ mesh, while Unit 5 deposit was dry sieved over $6 \mathrm{~mm}$ mesh to examine the effect of mesh size on the recovery of faunal remains.

The stratigraphy was similar in both of the backcove units and consisted of an upper deposit of dark brown silty soil underlain by a grey sandy silt, followed by a grey-yellow beach sand at $130-240 \mathrm{~cm}$ depth containing abundant marine shell midden, fragments of limestone and smaller amounts of pottery, fish bone and a few shell and stone artefacts. In Unit 5, Layer 2 was a grey ashy soil that did not occur in Unit 4, and in Layer 4 (Unit 5) there was a linear arrangement of coral and limestone boulders (Figure 2). The basal deposit (Layer 6 in Unit 5 and Layer 5 in Unit 4) contained abundant remains of marine shellfish, particularly intact and broken valves of Tridacnids mixed together with ceramics tempered with a distinctive calcareous-volcanic sand (Fitzpatrick, 2003; Clark, 2005). Palaeoshoreline records indicate that Palau has been subsiding at a rate of $\sim 0.55 \mathrm{~mm}$ since the mid-Holocene (Dickinson and Athens, 2007), and consistent with subsidence was the presence of edge erosion on ceramic sherds and absence of macro-charcoal in the basal cultural deposit (Wright, 2005: 190).

\section{Radiocarbon dating}

Charcoal (3), pot residues (2) and marine shell (7) samples from Units 4 and 5 were radiocarbon dated at 


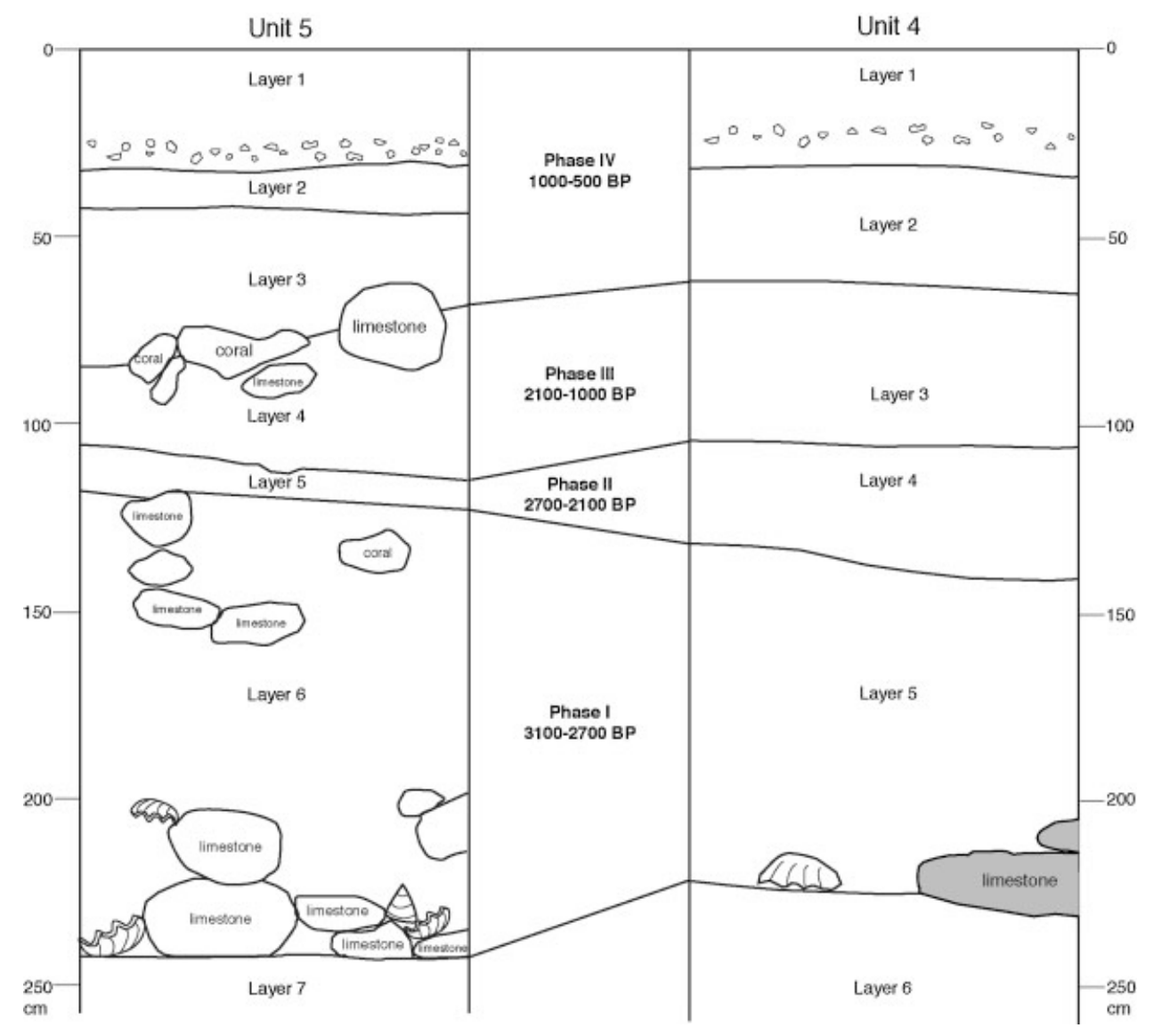

Figure 2. Stratigraphy of Units 4 and 5 and Phase I-IV sediments.

the Waikato and ANU dating laboratories (Table 1). Samples were subjected to standard pretreatments, and the marine shell samples dated by the Waikato Laboratory were examined for recrystallisation (Clark et al., 2006). Calibrations at $2 \sigma$ were made with the CALIB Rev 5.0.1 software using the bidecadal curves for charcoal determinations of Stuiver \& Reimer (1993) and Stuiver \& Braziunas (1993) with $\Delta R$ set at $75 \pm 68$ years for marine shell dates (Petchey \& Clark, 2010).

The ${ }^{14} \mathrm{C}$ results are in reasonable chronological order except for ANU-12119 (2780-1900 cal. BP) on charcoal, which was suspected to be intrusive from

Table 1. Radiocarbon dates from Units 4 and 5, Ulong Island

\begin{tabular}{|c|c|c|c|c|c|c|}
\hline Laboratory number & CRA & ${ }^{13} \mathrm{C}$ & Cal. BP (2SD) & Sample & Context & Phase \\
\hline Wk-15645 & $582 \pm 49$ & $-25.6 \pm 0.2$ & 530-660 & Charcoal & U4, 30-40 cm & IV \\
\hline aWk-13777 & $2260 \pm 48$ & $-27.0 \pm 0.2$ & $2150-2350$ & Pot residue & $\mathrm{U} 4,110 \mathrm{~cm}$ & II \\
\hline ANU-12114 & $2930 \pm 70$ & $0.0 \pm 2.0 \mathrm{Est}$ & $2340-2800$ & Tridacna sp. & $\mathrm{U} 4,110-120 \mathrm{~cm}$ & II \\
\hline ANU-12113 & $2650 \pm 130$ & $-24.0 \pm 2.0$ Est & 2360-3040 & Charcoal & U4, $110-120 \mathrm{~cm}$ & II \\
\hline Wk-15646 & $3094 \pm 36$ & $2.9 \pm 0.2$ & $2650-3010$ & Tridacna sp. & U4, $150-160 \mathrm{~cm}$ & i \\
\hline Wk-14357 & $2471 \pm 39$ & $-27.5 \pm 0.2$ & $2360-2710$ & Pot residue & U4, $170-180 \mathrm{~cm}$ & 1 \\
\hline Wk-15647 & $3358 \pm 40$ & $2.3 \pm 0.2$ & 2900-3330 & Hippopus sp. & U4, $200-210 \mathrm{~cm}$ & i \\
\hline ANU12115 & $3210 \pm 80$ & $0.0 \pm 2.0$ Est & $2720-3210$ & Tridacna sp. & $\cup 4,220-230 \mathrm{~cm}$ & 1 \\
\hline ANU-12116 & $3230 \pm 60$ & $0.0 \pm 2.0$ Est & 2750-3190 & Tridacna sp. & U4, 220-230 cm & I \\
\hline${ }^{b}$ ANU-12119 & $2330 \pm 180$ & $-24.0 \pm 2.0$ Est & 2150-2690 & Charcoal & U5, $230-240 \mathrm{~cm}$ & i \\
\hline ANU-12118 & $3110 \pm 60$ & $-0.0 \pm 2.0$ Est & 2610-3070 & Tridacna sp. & U5, $230-240 \mathrm{~cm}$ & 1 \\
\hline ANU-12120 & $3330 \pm 80$ & $-0.0 \pm 2.0$ Est & 2820-3340 & Hippopus sp. & U5, $230-240 \mathrm{~cm}$ & I \\
\hline
\end{tabular}

${ }^{a}$ Dated carbonised residue from the interior surface of a complete pot dug into Phase II surface (see Clark \& Wright, 2007 for details).

b Sample ANU-12119 is considered to be intrusive charcoal from upper levels (see Petchey \& Clark, 2010). 
upper levels as no macro-charcoal was recorded in the lowest cultural deposit (Wright, 2005: 190). The determination is rejected as it is also out of sequence with five marine shell dates that indicate human use of the site at $\sim 3100-2900$ cal. BP. The stratigraphy, radiocarbon dates and ceramics, particularly the distribution of diagnostic rim forms and tempers can be used to divide the stratigraphy into four temporal phases (Wright, 2005: 62-89). Phase I represents the earliest deposit (Layer 5/Unit 4 and Layer 6/Unit 5) and is dated to $3100-2700 \mathrm{cal}$. BP. Cultural remains in Phase I were globular jars, some red-slipped, with everted rims and a distinctive volcanic-calcareous sand temper. Phase II equates with Layer 4/Unit 4 and Layer 5/Unit 5, and dates to 3000-2150 cal. BP, but based on the ceramic sequence of thin 'back curve' vessels the deposit has a probable age of 2700-2100 cal. BP (see also Wright, 2005: 52-53 and Clark \& Wright, 2007). Layer 3 in Unit 4 and Layer 4 in Unit 5 corresponds to Phase III described as the 'Intensification period' by Wright (2005: 48), but no radiocarbon dates were acquired from this deposit, and its age has to be estimated from change in the cultural sequence and the dating of overlying sediments. Phase IV contains distinctive thick grog-tempered flange-rim vessels (Layers 1-2/Unit 4) that are associated with stonework villages throughout Palau and date to the last 800 years, consistent with an age of 530-660 cal. BP on charcoal from $30-40 \mathrm{~cm}$ (Table 1). Ceramics below the Phase IV flange-rim bowls (Layer 3/Unit 4 and Layer 4/Unit 5) consist of a grog-tempered bowl assemblage with direct rims, some of which have an exterior channel groove below the lip. These vessels appear to directly precede the Phase IV flange rim bowls. Given the absence of radiocarbon dates and intermixing of ceramics in the deposit (Wright, 2005) we conservatively estimate Phase III (Layer 3/Unit 4) as spanning 2100-1000 cal. BP.

\section{Fish bone analysis}

\section{Method}

Fish remains were returned to the Australian National University for detailed study using the methods developed by Ono and others for analysing tropical fish remains from Island Southeast Asia (e.g. Ono, 2003, 2004, 2006; Campos, 2009), Oceania (e.g. Leach \& Davidson, 1977; Leach, 1986; Masse, 1989; Butler, 1988; Walter, 1998; Vogel, 2005; Intoh \& Ono, 2006; Ono \& Intoh, in press) and Okinawa (e.g. Toizumi, 2007). Identifications were based on cranial elements, special elements, vertebrae and teeth. Cranial elements used were the maxilla premaxilla, dentary, articulate, quadrate, pharyngeal clusters, opercular, preopercular, hyomandibular, palatine, cleithrum, supra-cleithrum, post-temporal, scapula, ephiyal and ceratohyal. Special elements were the dorsal spines of Balistidae (triggerfish) and Acanthuridae (unicornfish), scale of Ostrachiidae (boxfish), spines of Diodontidae (porcupinefish), scute of Carangidae (trevelley) and Acanthuridae (unicornfish) and caudal peduncle of Scombridae (tuna). Teeth were used for identification of sharks, triggerfish, and one species in Lethrinidae (Monotaxis granoculis or sea breams). Vertebrae (thoracic and caudal peduncle) were used for the identification of Elasmobranchii (mainly sharks) and some bony fish families such as Scombridae, Carangidae, Belonidae, Muraenidae, Siganidae, Balistidae and Scaridae. Many pelagic fishes such as Scombridae can be identified by their vertebrae rather than by fragile cranial elements, which frequently do not preserve in archaeological deposits (see Leach et al., 1997; Davidson et al., 1999; Ono \& Intoh, in press).

All fish bones from each excavation unit and level of Unit 4 and Unit 5 were designated as an assemblage and grouped to one of the four chronological phases outlined previously. Following the method of Leach (1986), each assemblage was sorted into identifiable remains and unidentifiable remains, with identifiable bones sorted anatomically and re-bagged. Bones were identified mainly to family while a few bones were identified to species or genera, and checked with comparative specimens at the ANH Osteology Laboratory (ANU). The Minimum Number of Individuals (MNI) and Number of Identified Specimens (NISP) were calculated (e.g. Leach, 1986), although element size mismatches were also taken into account (e.g. Ono, 2003, 2004, 2006; Intoh \& Ono, 2006; Ono \& Intoh, in press). The exception was shark vertebra as an individual can have large and small vertebra.

A total of 12308 fish bones were counted from the two $1 \mathrm{~m} \times 1 \mathrm{~m}$ units (Units 4 and 5 ). The rank of the 29 identified anatomical elements is shown in Table 2. Vertebrae were the most common element, with the major cranial bones ranked from 5 to 13 (maxilla 5; pharyngeal (upper cluster) $7 ;$ pharyngeal (lower cluster) $10 ;$ articular $11 ;$ quadrate 13 ). The total number of fish remains identified to the family level was 564 (MNI) and 1711 (NISP) in Unit 4, and 414 (MNI) and 995 (NISP) in Unit 5. Twenty-five taxa were identified including 19 families and one species (Monotaxis granoculis). The MNIs of Scarids (parrotfish) were the highest and made up about 20\% of total MNI in Units 4 and 5 (Tables 3 and 4). Lethrinids (emperors) 
Table 2. Rank and number of identified fish bone elements from Units 4 and 5, Ulong Island

\begin{tabular}{|c|c|c|c|c|}
\hline Anatomy & Rank & Unit 4 & Unit 5 & Total \\
\hline Vertebrae (bony fish) & 1 & 1282 & 448 & 1730 \\
\hline Spines & 2 & 519 & 230 & 749 \\
\hline Tooth(b) & 3 & 223 & 120 & 343 \\
\hline Premaxilla & 4 & 222 & 169 & 391 \\
\hline Dentary & 5 & 165 & 138 & 303 \\
\hline Spine (Diodontidae) & 6 & 165 & 75 & 240 \\
\hline Maxilla & 7 & 151 & 70 & 221 \\
\hline Pharyngeal (Upper) & 8 & 108 & 89 & 197 \\
\hline Scale & 9 & 61 & 130 & 191 \\
\hline Pharyngeal (Lower) & 10 & 93 & 92 & 185 \\
\hline Articulate & 11 & 121 & 49 & 170 \\
\hline Dorsal Spines & 12 & 90 & 66 & 156 \\
\hline Quadrate & 13 & 96 & 55 & 151 \\
\hline Caudal Peduncle & 14 & 92 & 34 & 126 \\
\hline Preopercle & 15 & 76 & 35 & 111 \\
\hline Cleithrum & 16 & 61 & 43 & 104 \\
\hline Vertebrae (sharks) & 17 & 35 & 51 & 86 \\
\hline Hyomandibular & 18 & 59 & 25 & 84 \\
\hline Scute & 19 & 59 & 17 & 76 \\
\hline Epihyal & 20 & 27 & 13 & 40 \\
\hline Supracleithrum & 21 & 21 & 12 & 33 \\
\hline Vomor & 22 & 21 & 8 & 29 \\
\hline Palatine & 23 & 16 & 13 & 29 \\
\hline Pharyngeal (Centre) & 24 & 19 & 8 & 27 \\
\hline Scapula & 25 & 16 & 7 & 23 \\
\hline Opercle & 26 & 19 & 3 & 22 \\
\hline Posttemporal & 27 & 13 & 4 & 17 \\
\hline Ceratohyal & 28 & 8 & 3 & 11 \\
\hline Tooth(s) & 29 & 2 & 0 & 2 \\
\hline Sub-total & & 3840 & 2007 & 5847 \\
\hline Others & & 185 & 62 & 247 \\
\hline Fragments & & 4528 & 1686 & 6214 \\
\hline Total & & 8553 & 3755 & 12308 \\
\hline
\end{tabular}

and Serranids (groupers) were major fish taxa in both units. Overall, inshore/reef habitat fish species were dominant in the assemblages. Of the outer-reef/pelagic species, the shark bones were classified into four taxa including two families (Carcharhinids and Lamnids) based on vertebrae morphology. Scombrids (tunas), Carangids (trevallies or scads) and Sphyraenids (barracudas) were present, but in much smaller numbers than those of inshore species.

The Unit 4 excavation resulted in a total count of 8553 fish bones while Unit 5 had 3755 fish bones, with the water-sieved Unit 4 deposit ( $3 \mathrm{~mm}$ mesh) producing more than double the number of fish bones compared to Unit 5 that was dry sieved through $6 \mathrm{~mm}$ mesh. The excavation units were $8 \mathrm{~m}$ apart and the Shannon-Weaver index $(H)$ was used to compare species diversity in the MNI of the two assemblages. A similar index value (Unit 4, $H=2.56$ and Unit 5, $H=2.45)$ indicates that mesh size and location did not have a significant effect on assemblage diversity. This suggests that mesh size influences MNI fish abundance rather than $\mathrm{MNI}$ fish species diversity as long as a variety of elements are used to identify taxa and small species were not an important part of the catch (see also Clark \& Szabó, 2009).

\section{Temporal change in fish taxa}

The major fish taxa exploited during the early period (Phase I: 3100-2700 cal. BP) in Unit 4 were inshore fish species such as Scarids, Acanthurids (unicornfish), Lethrinids, Serranids, Balistids (triggerfish) and Muraenids (moray eels). The total MNI of Scarids (22.5\%), Acanthurids (16.9\%) and Lethrinids (14.6\%) was higher than those of other taxa (see Table 3). A relatively high proportion of Balistids (10.1\%) and Muraenids (6.7\%) is another aspect of the fish catch during Phase I.During Phase I, fewer fish taxa were exploited compared to later phases (Phases III-IV). The number and variety of outer-reef/pelagic fish species was particularly limited as no Scombrids were identified in either Unit 4 or Unit 5, and only a single shark bone (vertebra) was found in the early Unit 4 cultural deposit. Carangids appear to be the only outerreef fish exploited during Phase I. Although not all species within a family may be caught the same way, some members of Carangids, particularly small species, frequent the inner reef and coast and can be captured by netting (e.g. Ono, 2009; Ono, 2010).

In Phase II (2700-2100 cal. BP) there are no major changes in either fish taxa variety or in the ratio of each fish taxa to the total MNI, which indicate that similar capture methods and fishing strategies to those of Phase I were employed. Sparse remains from Scombrids and Sphyraenids indicate that pelagic species were occasionally taken, although as in Phase I, sharks were rare/absent.

During Phase III, which appears on the available evidence to correspond to 2100 to $1000 \mathrm{cal}$. BP, there is a new trend in marine use in the archaeological record. This includes the presence of sharks including Lamnids (mackerel sharks), and an increasing amount of Labrids, Holocentrids (surgeonfish), Letbrinus sp. and Serranids in the total MNI, while the proportion of Acanthurids (11.0\%) decreases from that of Phases I and II (16.9-14.4\%) in Unit 4. The ratio of Siganidae and Monotaxis sp. in the total MNI also decreases slightly compared to Phase I.

The Phase III changes in fish use become significantly stronger in Phase IV (1000-500 BP). Scombrids (3.2-3.9\%), Holocentrids (2.3\%), Serranids (12.0$14.5 \%)$, Monotaxis sp. and Labrids (6.9-8.2\%) increase in total MNI, while Acanthurids (4.6-8.6\%) and Scarids (about 20\%) decrease. In contrast, Balistids, 


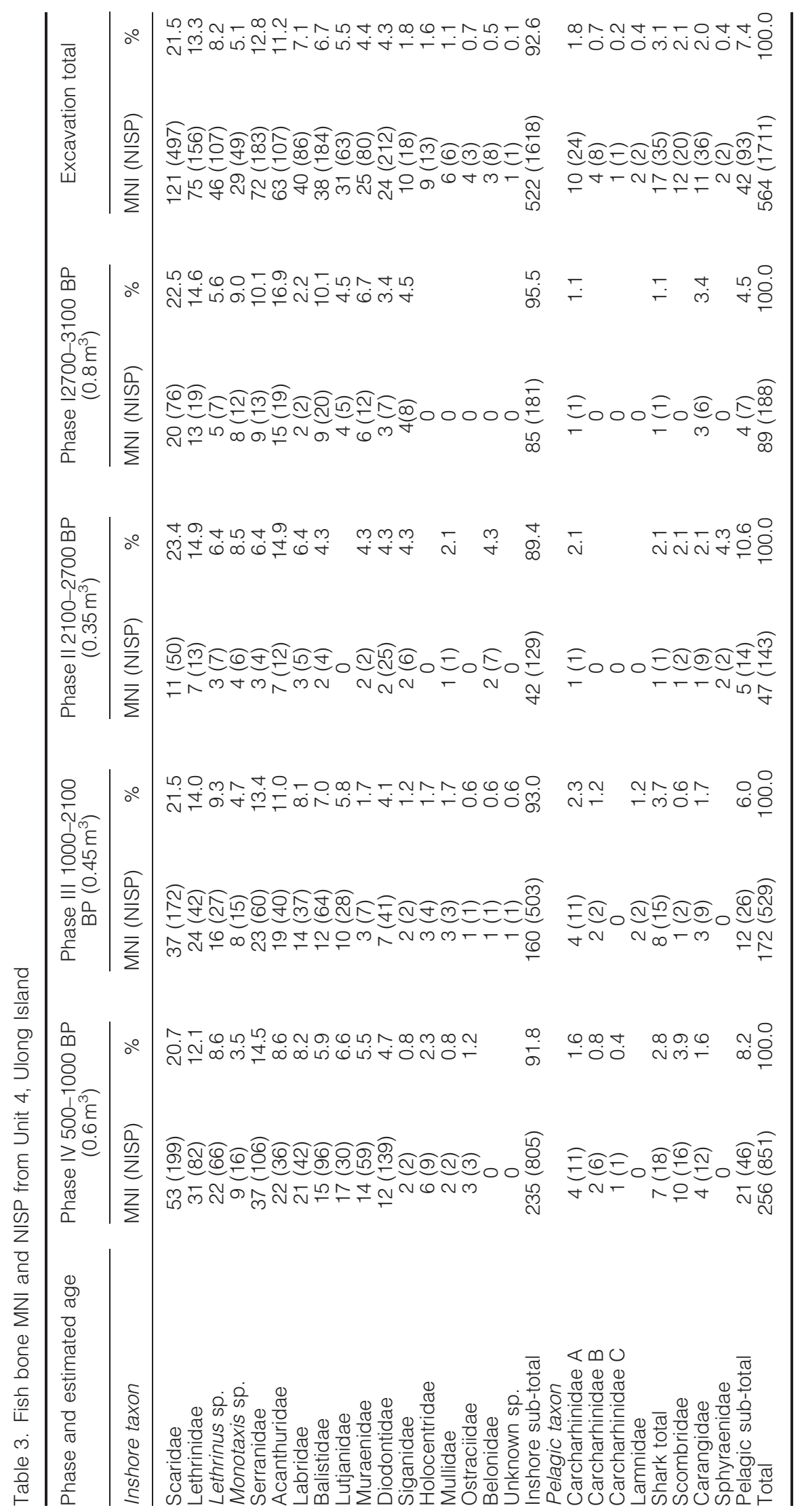




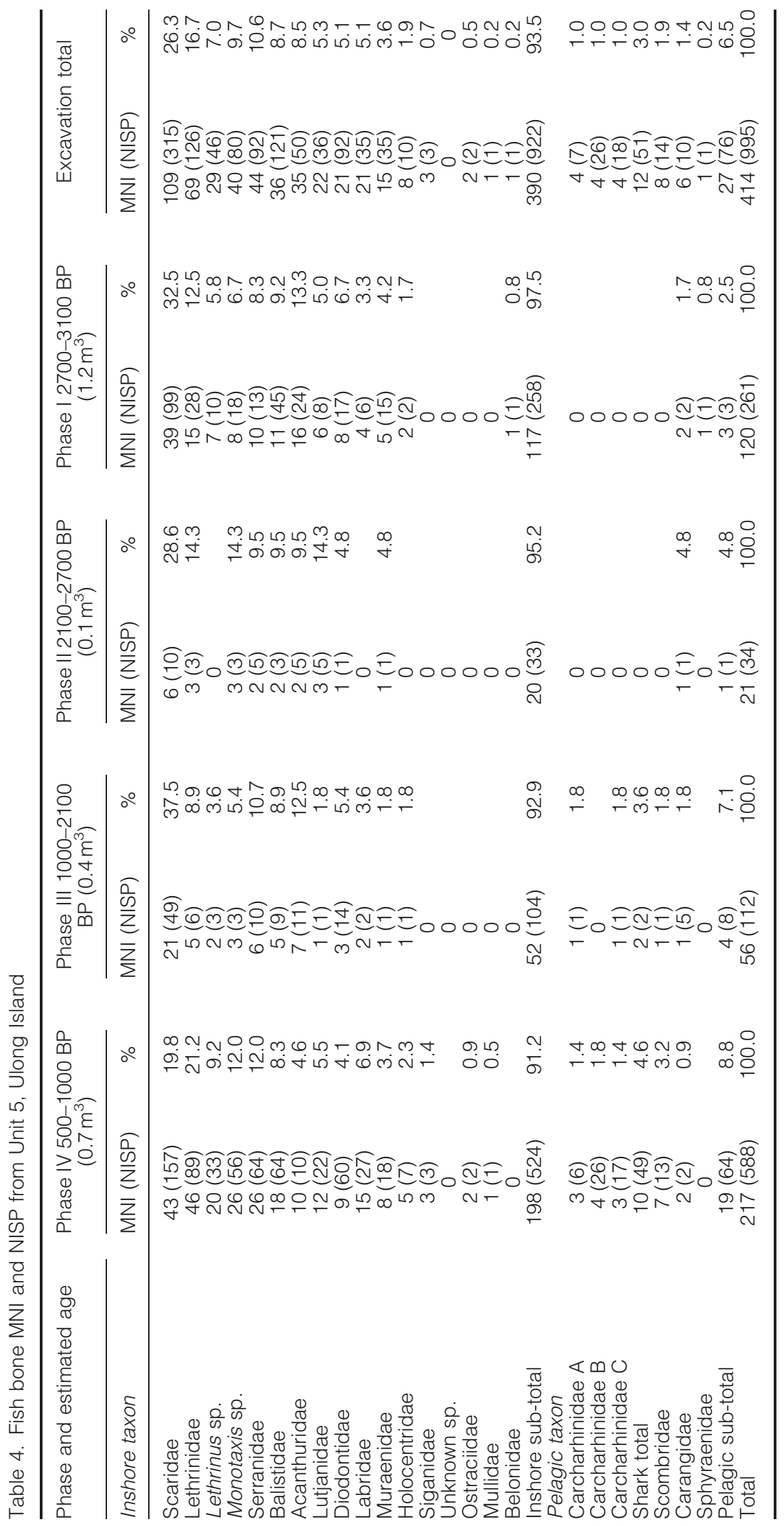


Lethrinids and Lutjanids tend not to change dramatically between early and late phases (except Lethrinids in Phase IV, Unit 5), and these fish were continually exploited in prehistory (Tables 3 and 4 ).

The fish bones from Units 4 and 5 suggest that the number of taxa increased over time as did the quantity of fish taken. To examine the first hypothesis of increasing taxa diversity, the Shannon-Weaver index $(H)$ was calculated on the MNI of Phase IV (500-1000 BP) and Phase I (3100-2700 BP) assemblages. The larger the value of $H$, the greater species diversity. In Unit 4, Phase IV $H=2.53$, and in Phase I $H=2.30$, while in Unit 5, Phase IV $H=2.44$, and in Phase I $H=2.19$. The greater diversity in the late-prehistoric fish assemblages of both units is not due to differences in sediment volume (Tables 3 and 4 ) as the Phase I deposits are larger than those of Phase IV, but Phase I has the lowest diversity of taxa. The second hypothesis of an increasing quantity of fish over time was assessed through the Mann-Whitney test on the NISP values for Phase IV and Phase I. NISP was used because MNI tends to underestimate the actual number of specimens, particularly sharks. In Unit 4 , the $p=0.034$ and in Unit 5 , the $p=0.009$ indicating significant differences. The
Mann-Whitney rank values are higher for Phase IV than Phase I indicating significantly more fish remains in the Phase IV collections.

\section{Marine sbellfish}

Marine shellfish remains were counted (NISP/MNI) and weighed in the field with voucher specimens retained for identification and radiocarbon dating. The analysis of shell remains from Unit 4 by Wright (2005: 97) showed a focus on a narrow set of taxa in the early Phase I assemblage dominated by large valves of Tridacna sp. and Hippopus bippopus along with sizeable individuals of Lambis lambis and Trocbus niloticus, and this pattern is also found in the previously unpublished Unit 5 shellfish assemblage where $74 \mathrm{~kg}$ of Tridacnid remains were recovered from the basal deposit (Table 5). In Phase I, marine shellfish, mostly Tridacnids, by weight contributes $77 \%$ of the total assemblage in Unit 4 and $88 \%$ of the total in Unit 5 , compared to Phase IV where shellfish is $9 \%$ of the total in Unit 4 and only $4 \%$ of the total in Unit 5 . The greater amount of shellfish in Phase IV exists after

Table 5. Shellfish NISP, MNI and Weight (g) from Unit 5, Ulong Island

\begin{tabular}{|c|c|c|c|c|c|c|c|c|c|c|c|c|}
\hline \multirow[b]{2}{*}{ Taxon } & \multicolumn{3}{|c|}{ Phase IV $\left(0.7 \mathrm{~m}^{3}\right)$} & \multicolumn{3}{|c|}{ Phase III $\left(0.4 \mathrm{~m}^{3}\right)$} & \multicolumn{3}{|c|}{ Phase $\|\left(0.1 \mathrm{~m}^{3}\right)$} & \multicolumn{3}{|c|}{ Phase I $\left(1.2 \mathrm{~m}^{3}\right)$} \\
\hline & NISP & $\mathrm{MNI}$ & Weight (g) & NISP & $\mathrm{MNI}$ & Weight (g) & NISP & $\mathrm{MNI}$ & Weight (g) & NISP & $\mathrm{MNI}$ & Weight (g) \\
\hline Tridacna gigas & 0 & 0 & 0 & 0 & 0 & 0 & 0 & 0 & 0 & 2 & 2 & 18600 \\
\hline Tridacna sp. & 139 & 4 & 0 & 23 & 4 & 5150 & 11 & 1 & 1156 & 236 & 11 & 23835 \\
\hline Hippopus hippopus & 2 & 1 & 3678 & 1 & 1 & 48 & 1 & 0 & 30 & 193 & 36 & 31500 \\
\hline Trochus & 3 & 1 & 18 & 3 & 2 & 108 & 5 & 2 & 54 & 57 & 18 & 2328 \\
\hline Conus & 2 & 2 & 92 & 1 & 1 & 82 & 1 & 1 & 2 & 16 & 10 & 151 \\
\hline Atactodea striata & 5 & 5 & 176 & 0 & 0 & 0 & 34 & 34 & 24 & 1483 & 1453 & 2423 \\
\hline Cypraea & 0 & 0 & 12 & 1 & 0 & 4 & 0 & 0 & 0 & 6 & 3 & 162 \\
\hline Lambis lambis & 5 & 3 & 0 & 8 & 2 & 1636 & 4 & 2 & 300 & 82 & 18 & 4082 \\
\hline Periglypta puerpera & 0 & 0 & 36 & 0 & 0 & 0 & 1 & 0 & 0 & 42 & 9 & 276 \\
\hline Trachycardium & 0 & 0 & 0 & 1 & 0 & 1 & 6 & 0 & 8 & 25 & 7 & 55 \\
\hline Anadara antiquata & 6 & 5 & 0 & 0 & 0 & 0 & 0 & 0 & 0 & 13 & 11 & 181 \\
\hline Turbo & 2 & 2 & 84 & 4 & 1 & 38 & 7 & 7 & 8 & 20 & 18 & 84 \\
\hline Strombus & 0 & 0 & 0 & 1 & 1 & 2 & 4 & 4 & 6 & 92 & 93 & 405 \\
\hline Nerita & 0 & 0 & 0 & 0 & 0 & 0 & 0 & 0 & 0 & 21 & 19 & 31 \\
\hline ?Geloina & 0 & 0 & 0 & 0 & 0 & 0 & 1 & 1 & 10 & 34 & 3 & 140 \\
\hline Tellina & 0 & 0 & 0 & 0 & 0 & 0 & 0 & 0 & 0 & 2 & 1 & 4 \\
\hline Fimbria fimbriata & 0 & 0 & 0 & 0 & 0 & 0 & 0 & 0 & 0 & 3 & 1 & 14 \\
\hline Isognomon & 0 & 0 & 0 & 0 & 0 & 0 & 0 & 1 & 2 & 9 & 3 & 27 \\
\hline Liochoncha & 1 & 1 & 0 & 0 & 0 & 0 & 0 & 0 & 0 & 6 & 5 & 226 \\
\hline Gafrarium & 3 & 0 & 2 & 0 & 0 & 0 & 1 & 0 & 2 & 4 & 3 & 12 \\
\hline Asaphis & 1 & 1 & 6 & 0 & 0 & 0 & 0 & 0 & 0 & 1 & 1 & 2 \\
\hline Fragum & 1 & 0 & 1 & 0 & 0 & 0 & 0 & 0 & 0 & 0 & 0 & 0 \\
\hline Polincia & 0 & 0 & 1 & 0 & 0 & 0 & 0 & 0 & 0 & 2 & 2 & 4 \\
\hline Thais & 0 & 0 & 0 & 0 & 0 & 0 & 0 & 0 & 0 & 1 & 1 & 4 \\
\hline Cerithium & 0 & 0 & 0 & 0 & 0 & 0 & 0 & 0 & 0 & 1 & 2 & 4 \\
\hline Residue & 0 & 0 & 0 & 0 & 0 & 14 & 0 & 0 & 76 & 0 & 0 & 3936 \\
\hline Total & 170 & 25 & 4106 & 43 & 12 & 7083 & 76 & 53 & 1678 & 2351 & 1730 & 88486 \\
\hline
\end{tabular}


correction for differences in sediment volume. In Unit 4 the sediment volumes are roughly similar (Phase IV $=0.6 \mathrm{~m}^{3}$, Phase $\mathrm{I}=0.8 \mathrm{~m}^{3}$ ), but the total weight of shellfish is only $7.2 \mathrm{~kg}$ in Phase IV, but $49 \mathrm{~kg}$ in Phase I. In Unit 5, the Phase IV volume $\left(0.7 \mathrm{~m}^{3}\right)$ produced $4.1 \mathrm{~kg}$ of shellfish, while the Phase I deposit $\left(1.2 \mathrm{~m}^{3}\right)$ had $88.5 \mathrm{~kg}$ of shellfish. Halving the Phase I shell weight to standardise deposit volumes still results in a Phase I shell weight more than 10 times that of Phase IV. In Figure 3, NISP and shell weights are plotted for each excavation unit (MNI values were not available
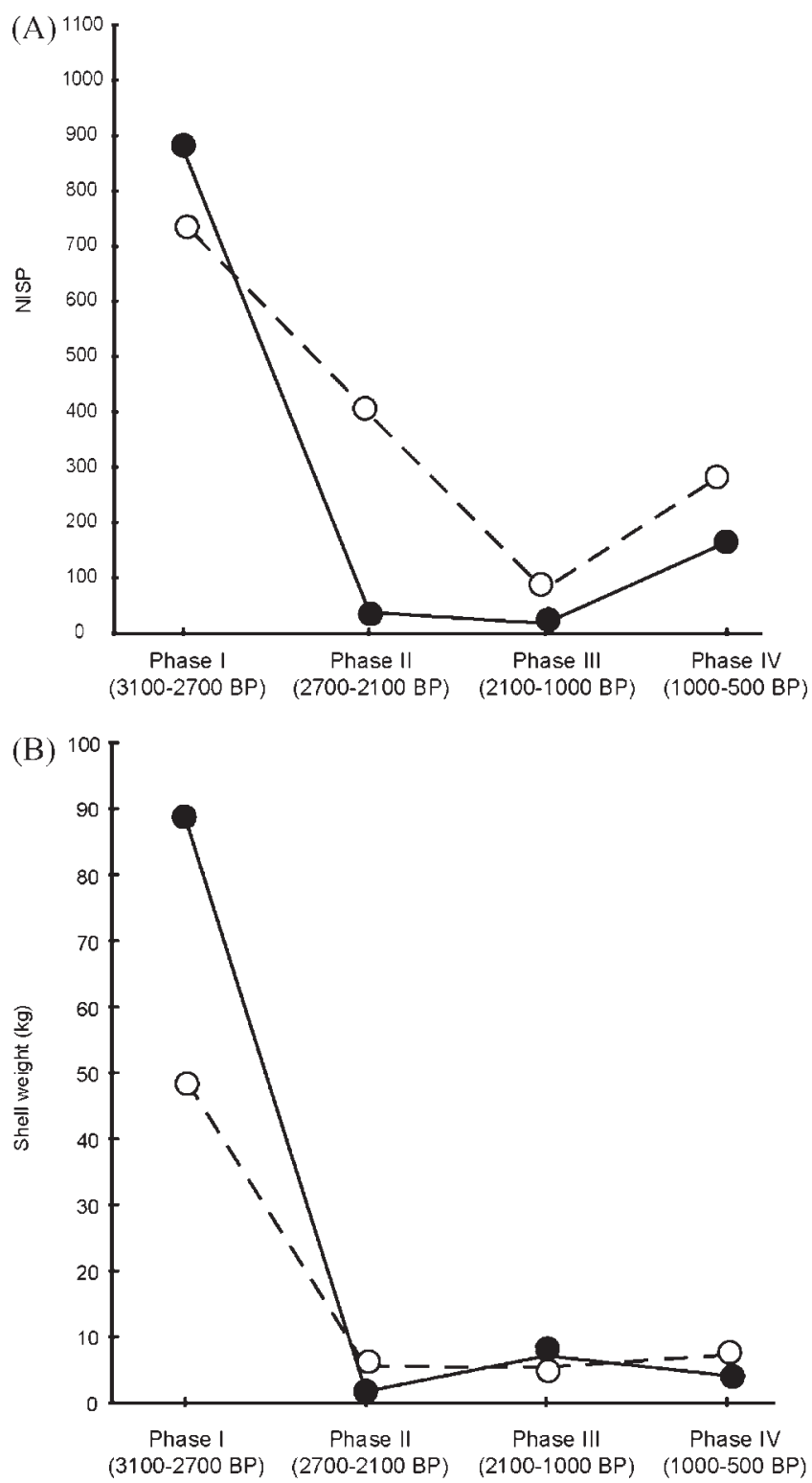

Figure 3. Shellfish remains from Units 4 and 5. (A) NISP and (B) shell weight $(\mathrm{kg})$. Filled circles $=$ Unit 5 and open circles $=$ Unit 4 . Note that Atactodea striata is not included in the NISP values as its small valves may have been wave deposited. for Unit 4), demonstrating a significant reduction in the amount of shellfish remains deposited after Phase I (3100-2700 cal. BP). A focus on a narrow range of large meat-yielding bivalves in Phase I suggests heavy exploitation of local stocks of Tridacnids.

Prehistoric people have had an impact on shellfish populations (Broughton, 1999), but natural influences such as storms, cyclones and mid-Holocene sea-level fall have also been implicated in local turnover and extinction of shellfish (Taylor, 1978; Loto'ahea \& Sone, 1995; Amesbury et al., 1996; Bourke et al., 2007). The number and weight of shellfish remains, especially Tridacnids, in Phase I, and the reduction in total shellfish in Phases III and IV could indicate that: (1) shellfish collection was an unimportant economic activity in Phase IV, (2) local shellfish stocks had been depleted by Phase III-IV or (3) there was a change in shellfish deposition in Phases III-IV when remains were no longer dumped in the back cove area.

In other parts of the Rock Islands, Phase IV stonework village deposits are associated with substantial marineshell midden debris indicating that shellfishing was important to late-prehistoric Palauan subsistence (Masse, 1989; Carucci, 1992; Clark \& Wright, 2005). Large Tridacnids were eaten fresh in Palau in the late-prehistoric era, and were generally returned entire to the settlement for consumption where the valves were used to make economic items, particularly shell adzes and ornaments (Keate, 1789: 192, 302, 312). The large quantity of Tridacnid remains in Phase I and their significant decline afterward suggests heavy predation of local shellfish stocks with only minor economic use of shell during short-term visits. By Phase IV large Tridacnids were not only less abundant around Ulong, but industrial use of large marine shells was more intensive in the stonework villages that contain large numbers of shell tools.

\section{Discussion}

The archaeological data for prehistoric fishing in Palau previously extended to around $2000 \mathrm{cal}$. BP (Fitzpatrick \& Kataoka, 2005), but there has been little information on marine exploitation during the period from 3100 to $2000 \mathrm{cal}$. BP. The fish and marine shell remains from the Ulong site indicate that collection of marine species was one of the most important subsistence activities in the Rock Islands. The composition of major fish taxa during Phases I and II highlight a focus on inshore species of fish, which have a broad habit that includes seaward reef flat, lagoonal patch reef, lagoonal sand flat, sea wall, surge channel and supralittoral or littoral pools (Johannes, 1981; Masse, 1989). 
Ethno-archaeological studies of contemporary fishing in the Southeast Asia and the Pacific (e.g. Kirch \& Dye, 1979; Wright \& Richards, 1985; Masse, 1989; Rolett, 1989; Ono, 2007, 2009; Ono \& Addison, 2009; Ono, 2010) as well as Butler's (1994) archaeolozoological study of fish-feeding behaviour and capture technique, indicate that the most effective method to capture slow-swimming fish with a small mouth (Scarids, Diondonts, Acanthurids and Balstids) is by netting and spearing, while angling is the usual method to capture fast swimming (or bottom dwelling) carnivorous large-mouthed fish of the Serranids, Lutjanids, Labrids, Scombrids, Holocentrids and mackerel sharks (Lamniformes). Reef sharks (Carcharhinidae) were commonly caught in Palau in the protohistoric era by spearing (Keate, 1789: 302). Fishing with a trolling lure is the main technique to capture fast swimming pelagic fish such as Scombrids and Sphyraenids. Some Lethrinids and Carangids are mainly caught by both netting and angling, while other species such as Monotaxis sp. (sea bream) and larger species are more frequently caught by angling.

Applying ethno-archaeological capture patterns to the archaeological fish assemblage from Ulong, it appears that netting, spearing and angling were important capture techniques. The MNIs of Scarids, Acanthurids, smaller sized Letbrinus sp. and Balistids ranges from $47.6-50.5 \%$ of the total $\mathrm{MNI}$, while the MNIs of Serranids, Lutjanids, Labrids and Monotaxis sp. occupied about $31 \%$ of the total MNI in both units, indicating that netting and spearing was more common than angling. The exploitation of Muraenids (about 4.5\%) may indicate trapping/spearing.

During Phase I, Ulong may have been used intermittently as there was only a narrow strip of low beach in front of the cove around 3100 years ago prior to the seaward expansion of the sand plain on which the Phase IV stonework village was located. After $2100 \mathrm{cal}$. BP, the relative abundance of outer-reef/ pelagic species increases as do several fish taxa that are frequently caught by angling. At the same time, the relative abundance of fish species usually caught by netting decreases. The decrease in Acanthurids and increase in Labrids, Scombrids and Holocentrids in the total MNI suggests that angling and trolling became more common after $1000 \mathrm{cal}$. BP.

Two possible factors for a change in the proportions of fish taxa on Ulong are that (1) angling and trolling techniques became increasingly common during the late prehistoric era, and, (2) increasing predation of inshore fish taxa, especially Scarids, Acanthurids and Balistids especially during Phases III and IV led to an increasing emphasis on the capture of outer-reef/ pelagic fish. In regard to the first possibility, we are unable to directly investigate changes in fish capture technology over time as no artefacts relating to angling, such as hooks and lures, were excavated from the site. However, numerous hooks $(n=175)$, lures $(n=9)$ and net sinkers $(n=179)$ were excavated from the Uchularois Cave site in the Rock Islands dating to Phases III and IV (see Masse, 1986: 109), and this provides tentative support for a change in capture strategies. Increasing quantities of fish were taken over time with the MNI of inshore taxa in Phase IV (1000$500 \mathrm{BP}$ ) also greater than in earlier phases. The effect of human predation on inshore taxa over time was examined in an analysis of cranial bones of Scarids and Monotaxis sp. by Wright (2005: 111), which indicated that the mean size of these taxa did not change significantly during prehistory, although there were relatively few elements measured from the early Phase I and II deposits.

To examine this issue further, we combined the Unit 4 and Unit 5 fish remains to increase the sample size, and for Scaridae measured the mid-width of the inferior pharyngeal cluster (see Masse et al., 2006: 121), and the height and mid-width of the dentary symphysis of Serranids (Mitutoyo brand accurate to $0.01 \mathrm{~mm}$ ). The number of Serranid dentaries was too small to statistically analyse, but there were sufficient Scarid bones from Phase I $(n=27)$, Phase II $(n=26)$ and Phase IV $(n=42)$, and these measurements are plotted in Figure 4a. Scarids from Phase I (3100-2700 cal. вP) have the largest measurements compared with those from Phase II (2700-2100 cal. BP) and Phase IV (1000500 cal. BP), which are the smallest, and in each phase there is a division between a main group with midwidth measurements under $20 \mathrm{~mm}$, and a small group containing a few large individuals with measurements larger than $25 \mathrm{~mm}$.

Scarids are common in the Palau lagoon with adults preferring the outer and seaward reefs while juveniles typically inhabit the lagoon (Golbuu et al., 2005: 502), suggesting that the few large individuals may have been taken from the outer reef. As Masse et al. (2006) noted, there are at least three genera/species of parrotfish represented in the Scaridae inferior pharyngeal remains with Type III, identified to Scarus sp., prominent in their collections and also in the Unit 4 and Unit 5 deposits. Measurements from the Ulong Type III parrotfish pharyngeals are plotted in Figure $4 \mathrm{~b}$ after removal of the large-sized outliers. A one-way ANOVA test (after homogeneity of variance was assessed) on the Phase I and Phase IV Scarus sp. inferior pharyngeals gave a statistically significant result $(F=4.262, \mathrm{df}=1 ; p=0.046)$. 

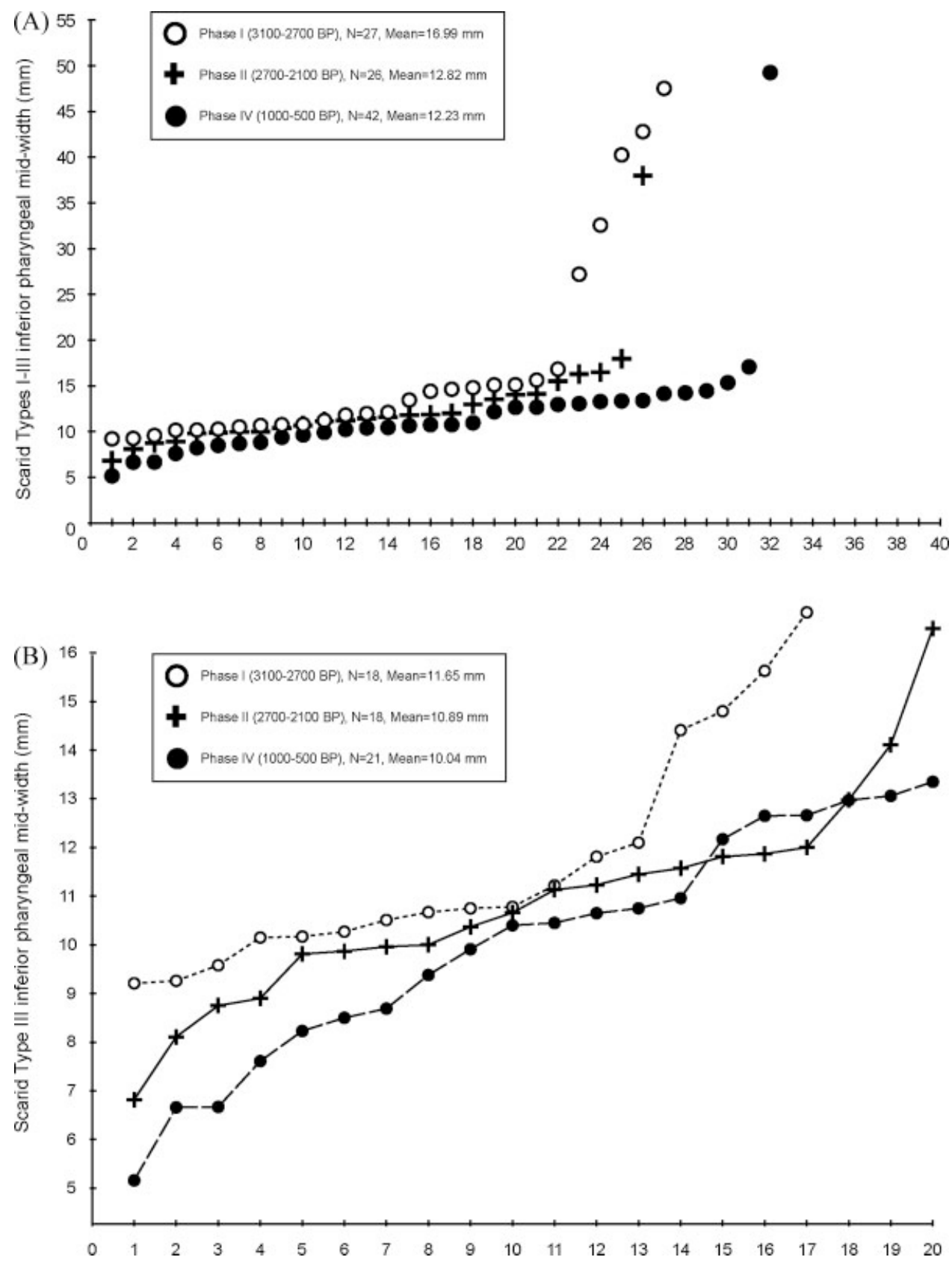

Figure 4. Scarid mid-width of the inferior pharyngeal cluster. (A) Scarid Types I-III with large individuals plotted. (B) Scarid Type III midwidths with large individuals removed.

A decrease in Scarid size from 3100 to 500 cal. BP is indicated, but the relatively small sample size involved and a $p$ value just below 0.05 mean that the results must be considered tentative until validated by measurements from large samples of fish bones from well-stratified deposits. We agree with Masse et al. (2006: 128) who found that in Palau, 'signatures of resource depletion and overharvesting are strongest at the beginning of the LIA (Little Ice Age, AD 1250-
1450), but also note that human predation of inshore fish stocks in the Rock Islands appear to have a lengthy history that predates the postulated LIA (see below).

The reason for a temporal shift in fish taxa at Ulong is uncertain and we compare our results with fish bone analyses from other parts of Palau to determine if the pattern in the Ulong assemblage is a local occurrence, or is found at other sites. Phases III-IV, which postdate $2100 \mathrm{cal}$. BP, correlate with the development of major 
earthworks on Babeldaob, and after 1000 cal. BP with the formation of 'traditional' stonework villages, both of which delineated socio-political districts/territories (e.g. Masse, 1986, 1989; Welch, 2001; Wickler, 2002; Wright, 2005; Masse et al., 2006; Liston, 2005, 2009). For this period, there are several prehistoric fish bone records from other parts of the Rock Islands. At the Chelechol ra Orrak site (Orrak Island), Layer 4 of Test Pit 2 and Layer 6 of Test Pit 1 are dated to about 20001600 cal. BP and about $1250 \mathrm{cal}$. BP, respectively (Fitzpatrick \& Kataoka, 2005:6), while the lower level (Layer 3) of Uchularois Cave site in the Ngemelis group is dated to 1350-1150 cal. BP (Masse et al., 1984; Masse, 1986, 1989).

Although the exact date range for the Ulong Phase III fish bone assemblage is uncertain, it most likely dates to 2100-1000 cal. BP, and we compare the Phase III remains (Layer 3/Unit 4 and Layer 4/Unit 5) with other assemblages in Palau. As shown in Table 6, one of the trends in these assemblages is the high abundance of Scarids which are $21.5-36.7 \%$ of the total MNI of identified fish taxa. Second, the relative abundance of Letbrinus sp. (5.3-9.3\%), Labrids (6.2-8.1\%), Balistids $(4.5-7.6 \%)$ and Lutjanids $(5.0-6.2 \%)$ is relatively even and these significant taxa were exploited in each location. The number of Elasmobranchii (mainly sharks) and pelagic species such as Scombrids is also similar in each assemblage.

In contrast, the relative abundance of Serranids, Acanthurids and Monotaxis sp. displays clear differences between sites. Serranids were highly exploited on Orrak Island at $21.8 \%$ of the total fish MNI in Test Pit 1 (Layer 6) dated to $1250 \mathrm{BP}$, while at the contemporary Uchularois site, Serranids were only $6.1 \%$. Acanthurids were highly exploited on Ulong $(11.0 \%)$, while at other locations they contributed only $1.8-3.4 \%$ of the total MNI. Monotaxis sp. were significant only at Uchularois Cave on Ngemelis group with $12.4 \%$ of the total MNI, while in other sites Monotaxis sp. was only $1.1-4.7 \%$. Apart from these differences, the overall pattern of fish taxa and the fishing strategy appears similar, with a focus on inshore fish and the use of netting and angling as major capture methods, along with minor use of spearing and trapping.

Table 6. Comparison of fish taxa from Phase III sites in Palau

\begin{tabular}{|c|c|c|c|c|c|c|c|c|}
\hline \multirow{2}{*}{$\begin{array}{l}\text { Site, layer and } \\
\text { estimated age } \\
\text { Taxon }\end{array}$} & \multicolumn{2}{|c|}{$\begin{array}{c}\text { Ulong/Unit4/ } \\
\text { Layer } 32100- \\
1000 \text { BP }\end{array}$} & \multicolumn{2}{|c|}{$\begin{array}{l}\text { Orrak/TP2/Layer } \\
4 \text { 2000-1600 BP }\end{array}$} & \multicolumn{2}{|c|}{$\begin{array}{c}\text { Orrak/TP1/Layer } \\
61250 \mathrm{BP}\end{array}$} & \multicolumn{2}{|c|}{$\begin{array}{l}\text { Uchularois/Layer } \\
3 \text { 1350-1150 BP }\end{array}$} \\
\hline & $\mathrm{MNI}$ & $\%$ & $\mathrm{MNI}$ & $\%$ & $\mathrm{MNI}$ & $\%$ & $\mathrm{MNI}$ & $\%$ \\
\hline Scaridae & 37 & 21.5 & 64 & 36.7 & 7 & 21.8 & 112 & 29.7 \\
\hline Serranidae & 23 & 13.4 & 21 & 12 & 7 & 21.8 & 23 & 6.1 \\
\hline Acanthuridae & 19 & 11.0 & 6 & 3.4 & 1 & 3.1 & 7 & 1.8 \\
\hline Lethrinus sp. & 16 & 9.3 & 14 & 8 & 3 & 9.3 & 20 & 5.3 \\
\hline Labridae & 14 & 8.1 & 14 & 8 & 2 & 6.2 & 29 & 7.6 \\
\hline Balistidae & 12 & 7.0 & 8 & 4.5 & 2 & 6.2 & 29 & 7.6 \\
\hline Lutjanidae & 10 & 5.8 & 9 & 5.1 & 2 & 6.2 & 19 & 5.0 \\
\hline Monotaxis sp. ${ }^{a}$ & 8 & 4.7 & 2 & 1.1 & 0 & & 47 & 12.4 \\
\hline Diodontidae & 7 & 4.1 & 2 & 1.1 & 1 & 3.1 & 11 & 2.9 \\
\hline Muraenidae & 3 & 1.7 & 5 & 2.8 & 1 & 3.1 & 12 & 3.1 \\
\hline Holocentridae & 3 & 1.7 & 2 & 1.1 & 0 & & 24 & 6.3 \\
\hline Mullidae & 3 & 1.7 & 5 & 2.8 & 0 & & 5 & 1.7 \\
\hline Siganidae & 2 & 1.2 & 1 & 0.5 & 0 & & 0 & \\
\hline Ostraciidae & 1 & 0.6 & 3 & 1.7 & 0 & & 5 & 1.7 \\
\hline Belonidae & 1 & 0.6 & 2 & 1.1 & 1 & 3.1 & 3 & 0.7 \\
\hline Haemulidae & 0 & & 1 & 0.5 & 1 & 3.1 & 0 & \\
\hline Kyphosidae & 0 & & 0 & & 0 & & 3 & 0.7 \\
\hline Scorpaenidae & 0 & & 1 & 0.5 & 0 & & 1 & 0.2 \\
\hline Mugilidae & 0 & & 1 & 0.5 & 0 & & 1 & 0.2 \\
\hline Tetradontidae & 0 & & 0 & & 0 & & 2 & 0.4 \\
\hline Scombridae & 1 & 0.6 & 0 & & 0 & & 9 & 2.3 \\
\hline Carangidae & 3 & 1.7 & 2 & 1.1 & 0 & & 8 & 2.1 \\
\hline Sphyraenidae & 0 & & 0 & & 0 & & 0 & \\
\hline Unknown sp. & 1 & 0.6 & 11 & 6.3 & 4 & 12.5 & 7 & 1.8 \\
\hline Total MNI & 164 & & 174 & & 32 & & 377 & \\
\hline Elasmobranchi $(N I S P)^{\mathrm{b}}$ & 15 & & 33 & & 19 & & 16 & \\
\hline
\end{tabular}

We identified Monotaxis sp. as Lethrinidae, but Masse (1986) identified them as Nemipetridae and Fitzpatrick \& Kataoka (2005) identified as Monotaxidae.

bTables 6 and 7 use the NISP value for Elasmobranchii as only NISP is reported by other researchers. 
During Phase IV (1000-500 cal. BP), the number of sites in the Rock Islands increased with at least 11 sizeable villages on several of the small coralline limestone islands between Peleliu and Koror (Masse, 1986: 85). Previous studies of village sites reveal they contain rich midden deposits, house platforms, community house or men's clubhouse platforms, long walls and extensive causeways (Takayama \& Takasugi, 1978; Osborne, 1979; Takayama et al., 1980; Masse et al., 1984; Snyder, 1989; Masse, 1986, 1989). Three prehistoric village sites on Mariar, Ngeanges and in the Ngemelis-Uchularois Group produced fish remains (Masse, 1986, 1989), and these assemblages are compared with the Phase IV fish bone assemblage from Ulong.

As shown in Table 7, a characteristic of Phase IV is the high proportion of Scarids in all sites with 20.7\% at Ulong and $40.1 \%$ at Uchularois Cave. However, the relative abundance of other major fish species is different at each location, particularly between Ulong and other parts of the Rock Islands. For instance, Acanthurids were only significant at Ulong (8.6\%), while at other locations, the proportion was very low at $0-1.2 \%$. At the same time, Monotaxis sp. was a major part of the catch at Ngeanges (8.5\%), Mariar (12.5\%) and in the Ngemelis Group (9.8-11.9\%), while at
Ulong, Monotaxis sp. was only 3.5\%. The relative abundance of Serranids varied from Ulong (14.5\%), Ngeanges (10.5\%) and Mariar (8\%), while at sites in the Ngemelis Group Serranids were 4.1-5.2\%. Only Labrids were highly exploited in the majority of sites (7.6-10.3\%), with a peak of $19.5 \%$ on Ngeanges.

Similarly, the relative abundance of outer-reef/ pelagic fish species is different at each location. The relative abundance of Scombrids was $3.9 \%$ on Ulong and $3.1 \%$ on Uchularois Cave on Ngemelis, but was only $0-0.7 \%$ elsewhere. It should be noted that the relative abundance of Scombrids at Ulong and at Uchularois Cave is slightly higher than that of the previous period. Although it is hard to compare the relative abundance of Elasmobranchii (mainly sharks) as only the NISP count is available, it is clear that all sites have some shark bones. Since the combined NISP of shark during Phase I and II on Ulong was very low $(\mathrm{NISP}=2)$, it is likely that capture of sharks becomes increasingly common in Phases III and IV where the combined NISP $=45$.

Masse (1989: 491) previously analysed several fish bone assemblages from the Rock Islands and suggested there had been a move away from outer-reef/pelagic species over time (Scombrids, Carangids, Serranids), representing a change in fishing techniques from

Table 7. Comparison of fish taxa from Phase IV sites in Palau

\begin{tabular}{|c|c|c|c|c|c|c|c|c|c|c|}
\hline \multirow{2}{*}{$\begin{array}{l}\text { Site, layer and } \\
\text { estimated age } \\
\text { Taxa }\end{array}$} & \multicolumn{2}{|c|}{$\begin{array}{l}\text { Ulong/Unit4/ } \\
\text { Layers 1-2 } \\
\text { 940-580 вP }\end{array}$} & \multicolumn{2}{|c|}{$\begin{array}{l}\text { Ngemelis } \\
700-550 \text { BP }\end{array}$} & \multicolumn{2}{|c|}{$\begin{array}{c}\text { Mariar } \\
700-550 \text { вр }\end{array}$} & \multicolumn{2}{|c|}{$\begin{array}{l}\text { Ngeanges } \\
700-550 \text { вр }\end{array}$} & \multicolumn{2}{|c|}{$\begin{array}{c}\text { Uchularois/ } \\
\text { Layer } 2 \\
\text { 1250-350 BP }\end{array}$} \\
\hline & $\mathrm{MNI}$ & $\%$ & $\mathrm{MNI}$ & $\%$ & $\mathrm{MNI}$ & $\%$ & $\mathrm{MNI}$ & $\%$ & $\mathrm{MNI}$ & $\%$ \\
\hline Scaridae & 53 & 20.7 & 90 & 37.1 & 87 & 35.2 & 34 & 25.5 & 316 & 40.1 \\
\hline Serranidae & 37 & 14.5 & 10 & 4.1 & 20 & 8.0 & 14 & 10.5 & 41 & 5.2 \\
\hline Acanthuridae & 22 & 8.6 & 3 & 1.2 & 1 & 0.4 & 0 & & 9 & 1.1 \\
\hline Lethrinus sp. & 22 & 8.6 & 6 & 2.4 & 13 & 5.2 & 8 & 6 & 42 & 5.3 \\
\hline Labridae & 21 & 8.2 & 25 & 10.3 & 24 & 9.7 & 26 & 19.5 & 60 & 7.6 \\
\hline Balistidae & 15 & 5.9 & 22 & 9 & 15 & 6 & 6 & 4.5 & 49 & 6.2 \\
\hline Lutjanidae & 17 & 6.6 & 5 & 2 & 9 & 3.6 & 4 & 3 & 43 & 5.4 \\
\hline Monotaxis sp. & 9 & 3.5 & 29 & 11.9 & 31 & 12.5 & 21 & 8.5 & 78 & 9.8 \\
\hline Diodontidae & 12 & 4.7 & 37 & 15.2 & 17 & 6.8 & 3 & 2.2 & 31 & 3.9 \\
\hline Muraenidae & 14 & 5.5 & 2 & 0.8 & 6 & 2.4 & 5 & 3.7 & 15 & 1.9 \\
\hline Holocentridae & 6 & 2.3 & 2 & 0.8 & 9 & 3.6 & 1 & 0.7 & 28 & 3.5 \\
\hline Mullidae & 2 & 0.8 & 1 & 0.4 & 1 & 0.4 & 1 & 0.7 & 19 & 2.4 \\
\hline Siganidae & 2 & 0.8 & 0 & & 0 & & 0 & & 0 & \\
\hline Ostraciidae & 3 & 1.2 & 0 & & 4 & 1.6 & 1 & 0.7 & 8 & \\
\hline Belonidae & 0 & & 0 & & 0 & & 0 & & 4 & \\
\hline Haemulidae & 0 & & 0 & & 1 & 0.4 & 0 & & 0 & \\
\hline Aluteridae & 0 & & 1 & 0.4 & 0 & & 0 & & 1 & \\
\hline Scorpaenidae & 0 & & 1 & 0.4 & 0 & & 0 & & 1 & \\
\hline Tetradontidae & 0 & & 2 & 0.8 & 1 & 0.4 & 3 & 2.2 & 0 & \\
\hline Scombridae & 10 & 3.9 & 0 & & 1 & 0.4 & 1 & 0.7 & 25 & 3.1 \\
\hline Carangidae & 4 & 1.6 & 3 & 1.2 & 4 & 1.6 & 4 & 3 & 11 & 1.3 \\
\hline Sphyraenidae & 0 & & 0 & & 0 & & 0 & & 0 & \\
\hline Unknown sp. & 0 & & 3 & 1.2 & 3 & 1.2 & 1 & 0.7 & 7 & \\
\hline Total MNI & 256 & & 242 & & 247 & & 133 & & 788 & \\
\hline Elasmobranchi (NISP) & 18 & & 66 & & 40 & & 13 & & 180 & \\
\hline
\end{tabular}


Table 8. Total count number (NISP and MNI) identified by 8 elements and 19 elements in Unit 4, Ulong Island

\begin{tabular}{|c|c|c|c|c|c|}
\hline Method & 8 elements $^{a}$ & 19 elements $^{b}$ & 8 elements & 19 elements & \\
\hline $\begin{array}{l}\text { Total count } \\
\text { number }\end{array}$ & NISP & NISP & $\mathrm{MNI}$ & $\mathrm{MNI}$ & \\
\hline \multicolumn{6}{|l|}{ Inshore Taxon } \\
\hline $\begin{array}{l}\text { Scaridae } \\
\text { Lethrinidae }\end{array}$ & 384 & 497 & 121 & 121 & \\
\hline Lethrinus sp. & 95 & 107 & 42 & 46 & $\uparrow$ \\
\hline Monotaxis sp. & 40 & 49 & 27 & 29 & $\uparrow$ \\
\hline Serranidae & 183 & 183 & 71 & 72 & \\
\hline Acanthuridae & 34 & 107 & 15 & 63 & $\uparrow \uparrow$ \\
\hline Labridae & 86 & 86 & 40 & 40 & \\
\hline Balistidae & 46 & 184 & 32 & 38 & $\uparrow$ \\
\hline Lutjanidae & 40 & 63 & 28 & 31 & $\uparrow$ \\
\hline Muraenidae & 23 & 80 & 14 & 25 & $\uparrow \uparrow$ \\
\hline Diodontidae & 186 & 212 & 20 & 24 & \\
\hline Siganidae & 0 & 18 & 0 & 10 & $\uparrow \uparrow$ \\
\hline Holocentridae & 5 & 14 & 4 & 10 & $\uparrow \uparrow$ \\
\hline Mullidae & 6 & 6 & 6 & 6 & \\
\hline Ostraciidae & 0 & 4 & 0 & 3 & $\uparrow$ \\
\hline $\begin{array}{l}\text { Belonidae } \\
\text { Pelagic Taxon }\end{array}$ & 3 & 8 & 2 & 3 & $\uparrow$ \\
\hline Scombridae & 3 & 20 & 3 & 12 & $\uparrow \uparrow$ \\
\hline Carangidae & 0 & 36 & 0 & 11 & $\uparrow \uparrow$ \\
\hline Sphyraenidae & 2 & 2 & 2 & 2 & \\
\hline Total & 1136 & 1676 & 427 & 546 & $\uparrow$ \\
\hline
\end{tabular}

a Dentary, premaxilla, maxilla, quadrate, articulate, phalyngeal clusters, scutes of Acanthurids, and dorsal spines of Balistids.

b 8 elements plus scute of Carangids, dorsal spine of Acanthurids, dermal spine of Diodontids, caudal peduncle of Scombrids, tooth, vertebra, preopercle, opercle, palatine, vomor, and scale. We used more elements for identification but did not encounter other elements identifiable to taxa in the Ulong assemblage.

$\uparrow$ : increase, $\uparrow \uparrow$ : increase significantly.

Table 9. Major skeletal elements and identified fish taxa

\begin{tabular}{|c|c|c|c|c|c|c|c|c|c|c|c|}
\hline Taxa & $\begin{array}{l}5 \text { major } \\
\text { elements }\end{array}$ & Pharyngeal & Tooth & Scute & Spine $^{a}$ & Preopercle & Opercle & Palatine & Cleithrum & Scale & Vertebra \\
\hline $\begin{array}{l}\text { Scaridae } \\
\text { Lethrinidae } \\
\text { Lethrinus sp. } \\
\text { Monotaxis sp. } \\
\text { Serranidae } \\
\text { Acanthuridae } \\
\text { Labridae } \\
\text { Balistidae } \\
\text { Lutjanidae } \\
\text { Muraenidae } \\
\text { Diodontidae } \\
\text { Siganidae } \\
\text { Holocentridae } \\
\text { Mullidae } \\
\text { Ostraciidae } \\
\text { Belonidae } \\
\text { Scombridae } \\
\text { Carangidae } \\
\text { Sphyraenidae }\end{array}$ & 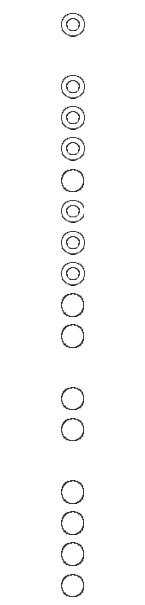 & $\begin{array}{l}\mathrm{e} \\
0\end{array}$ & $\begin{array}{l}\bigodot \\
\triangle \\
\triangle \\
\triangle\end{array}$ & (อ) & 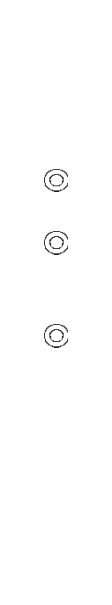 & $\begin{array}{l}\triangle \\
0 \\
\triangle \\
\triangle \\
\triangle \\
0\end{array}$ & $\begin{array}{l}\triangle \\
\triangle \\
\triangle\end{array}$ & $\begin{array}{l}\triangle \\
0 \\
0 \\
\triangle \\
\triangle\end{array}$ & $\begin{array}{l}\triangle \\
\triangle \\
\triangle\end{array}$ & (2) & 0 \\
\hline
\end{tabular}

$(\mathrm{O}=$ frequently confirmed in our analysis.

$\bigcirc=$ confirmed in our analysis.

$\triangle=$ confirmed by other analyses (Walter, 1998; Ono, 2003, 2004; Vogel, 2005).

a Spine includes dorsal spine of Balistids and Acanthurids, and dermal spines of Diodontids.

Copyright (C) 2010 John Wiley \& Sons, Ltd.

Int. J. Osteoarchaeol. (2010) 
angling to netting and spearing. This trend was not observed on Ulong (see also Wright, 2005: 108) and in fact angling appears to have been commonly employed in Phase IV as the number of outer-reef/pelagic species increased. If inshore species that are frequently caught by angling are included with pelagics then angling is likely to have been a common capture method throughout the Rock Islands. Although we do not discuss prehistoric fishing after $500 \mathrm{BP}$ as Ulong was abandoned at that time, our study clearly points to the importance of angling, and an increasing emphasis on the capture of fast swimming carnivorous fish species between 1000 and $500 \mathrm{cal} \mathrm{BP}$.

Concerning the methodology of our fish bone analysis, we confirm that the use of more skeletal elements including vertebrae can increase the total count (both NISP and MNI) and variety of fish taxa in the same assemblage (Table 8 ). Table 9 shows the list of major potential elements used to identify each fish family based on our analysis and in other studies (Walter, 1998; Ono, 2003, 2004; Vogel, 2005). As shown in Table 8 , the gains provided by use of an increased number of elements are greater than the results provided by the more traditional five paired mouth parts (dentary, premaxilla, maxilla, quadrate, articulate) and some other special elements (phalyngeal clusters, scutes of Acnathurids and dorsal spines of Balistids) mainly conducted in the 1980s in studies of Pacific fish assemblages (e.g. Leach, 1986). Such a trend is particularly strong for MNI of small sized species of Acanthurids, Siganids, Holocentrids and pelagic species such as Scombrids and Carangids, while the MNI of other major fish family including Scarids, Lethnids, Serranids, Labrids, Balistids and Diodontids did not change significantly even after increasing number of identification elements.

Our result clearly supports Butler's (1994) study which suggests that increasing the number of elements does not affect the relative faunal abundance of common fish species identified with the five paired mouth parts and other special elements (Butler, 1994: 85-86). However, our analysis also demonstrates that including some elements such as vertebrae, which are neglected in traditional archaeofaunal analysis of fish does affect the abundance of some fish families including pelagic and small sized species, and hence the total variety of fish taxa in an assemblage.

\section{Conclusion}

The long prehistoric record of marine resource use from Ulong suggests that early foraging focused on inshore species of fish and shellfish, especially Tridacnids, which may well have been locally extirpated. Large meat-yielding species were taken primarily for food as there is no evidence for intensive industrial use of Tridacna and Hippopus shell in the early deposits. The capture of outer-reef/pelagic taxa and increase in the number of taxa taken during Phases III-IV on Ulong, and at other sites in Palau, we suspect is largely due to human population growth and the development of economic adaptations, including in fishing, that in tandem with fresh-water procurement techniques, such as wells to tap the Ghyben-Herzberg lens, enabled permanent village settlements to flourish after $900 \mathrm{cal}$. BP.

These environments are difficult to occupy as they have limited horticultural potential, impermanent fresh water sources and few terrestrial foods (Masse et al., 2006), suggesting that marine resources were essential to human subsistence in the Rock Islands. Such precarious settlements were clearly tied to, and partially sustained by, their connections with communities on the main island of Babeldaob, and were engaged in both local and polity-scale conflict (Keate, 1789; Osborne, 1966: 401,403). While villages on the large southern islands of Peleliu and Angaur existed in late prehistory (Keate, 1789), it appears that those on the smaller islands south of Koror were largely abandoned by 500-400 cal. BP (Masse, 1989).

Masse et al. (2006) analysed faunal remains from Uchularois Cave in the Ngemelis Group dating from $\mathrm{AD}$ 650-1000 to $\mathrm{AD}$ 1250-1450, and recorded measurable decreases in the size of fish and shellfish remains consistent with over-harvesting by a stonework village population that was increasingly degrading the natural environment. Evidence for climate change, specifically the 'AD 1300 Event' proposed by Nunn (2007) was equivocal in the palaeoenvironmental and archaeological records reviewed by Masse and others, but a recent study by Sachs et al. (2009) using sensitive microbiological, isotopic and molecular indicators of rainfall in marine lake sediments indicate that Palau had a dryer climate at AD 1420-1560 due to the southward movement of the Pacific inter-tropical convergence zone (ITCZ).

The impact of dryer conditions on the natural environment, especially inshore fish and shellfish, and pelagic fish stocks is uncertain, yet decreasing precipitation is likely to have been a critical factor in the abandonment of the Rock Islands, whether through primary loss of potable water, or from secondary effects such as a decline in horticultural yields (in the Rock islands and on Babeldaob), and a concomitant increase in the frequency of inter-group aggression to control subsistence resources. Traditions state that Ulong was 
an important centre that was depopulated after being defeated by forces from Ngemelis and Peleliu (Osborne, 1966: 401, 403), but the demise of stone work villages in the Rock Islands is a complicated issue requiring additional fine-grained archaeological and palaeoenvironmental research.

Concerning mesh size on the recovery of fish bones, Butler (1994: 85) suggested that relative fish family abundance is similar across screen mesh fractions ( $3 \mathrm{~mm}, 5 \mathrm{~mm}$ and $7 \mathrm{~mm}$ ) based on materials excavated from Mussau, and that mesh dimensions did not skew the recovery of fish taxa in those assemblages. It is generally accepted that mesh size does affect the results of faunal analysis (Thomas, 1969), particularly the recovery of fish bones (e.g. Casteel, 1972; Nagaoka, 1994, 2005) and it is clear that the total number of fish bones, particularly of smaller-bodied species are more abundant in the Unit 4 assemblage that was sieved through $3 \mathrm{~mm}$ mesh. Although our study supports Butler's general conclusion (see also Clark \& Szabó, 2009), we consider that it is essential to employ fine mesh $(\leq 3 \mathrm{~mm})$ screening (see also Reitz et al., 2009: 17) in order to recover and identify all prehistoric fish taxa.

In addition, we recommend using more skeletal elements including vertebrae for fish identification as demonstrated here. Vertebrae are useful to identify Elasmobranchii, Scombrids, Carangids, Muraenids, Belonids and Scarids (see also Ono \& Intoh, in press). In line with the results of other studies that promote use of a large number of elements (e.g. Butler, 1988, 1994; Masse, 1986, 1989; Ono, 2003, 2004; Vogel, 2005; Walter, 1998), it is now clear that using a larger number of elements for identification can increase the total number of identified taxa and the abundance of individual taxa (both MNI and NISP). Once these increasingly detailed analyses are conducted on fish bone assemblages from Palau and other parts of the Pacific, we will be able to better understand prehistoric marine activity, especially the impact that humans and climate have had on marine ecosystems in the past.

\section{Acknowledgements}

We acknowledge the help of Atholl Anderson, Duncan Wright, Jolie Liston and the Belau Bureau of Arts and Culture especially the assistance of the late Rita Olsudong (National Archaeologist). The Ulong excavations were made with the permission of the Governor of Koror, the Honourable John Gibbons. Field investigations were made by Clark, Wright, Vince Blaiyok,
Dino Mibuk and Lark Ngirkiklang supported by a grant from the Australian Research Council to Clark. We particularly thank the two referees for their helpful comments and observations.

\section{References}

Allen MS. 2002. Resolving long-term change in Polynesian marine fisheries. Asian Perspective 41: 195-212.

Amesbury JR, Moore DR, Hunter-Anderson RL. 1996. Cultural adaptations and late Holocene sea level change in the Marianas: Recent excavations at Chalan Piao, Saipan, Micronesia. Bulletin of the Indo-Pacific Prebistory Association 15: 53-69.

Anderson A, Chappell J, Clark G, Phear S. 2005. Comparative radiocarbon dating of pottery and charcoal samples from Babeldaob Island, Republic of Palau. Radiocarbon 47(1): 152-158.

Beardsley FR. 1997. Fishponds, Taro Patches and Shell Middens: Archaeological Investigations on Peleliu, Republic of Palau, Data Recovery and Monitoring for the Palau Rural Water System Program. International Archaeological Research Institute, Inc.: Honolulu, Hawaii.

Bourke P, Brockwell S, Faulkner P, Meehan B. 2007. Climate variability in the mid to late Holocene Arnhem Land Region, North Australia: Archaeological archives of environmental and cultural change. Archaeology in Oceania 42: 91-101.

Broughton JM. 1999. Resource depression and intensification during the Late Holocene, San Francisco Bay: Evidence from the Emeryville shellmound vertebrate fauna. University of California Publications: Berkeley. Anthropological Records No. 32, University of California.

Butler V. 1988. Lapita fishing strategies: The faunal evidence. In Archaeology of the Lapita Cultural Complex: A Critical Review, Kirch PV, Hunt TL (eds). Thomas Burke Memorial Washington State Museum: Seattle; 99-115. Research Report 5.

Butler V. 1994. Fish feeding behavior and fish capture: the case for variation in Lapita fishing strategies. Archaeology in Oceania 29: 81-90.

Campos FZ. 2009. The Ichthyoarchaeology of Batanes Islands, Northern Philippines. M.A. Thesis, Department of Archaeology, University of Philippines.

Carucci J. 1992. Cultural and Natural Patterning in Prebistoric Marine Food Shell from Palau, Micronesia. University Microfilms International: Ann Arbor, MI.

Casteel RW. 1972. Some biases in the recovery of archaeological faunal remains. Proceedings of the Prebistoric Society 36: 382-388.

Clark G. 2004. Radiocarbon dates from the Ulong site in Palau and implications for Western Micronesian prehistory. Archaeology in Oceania 39(1): 26-33.

Clark G. 2005. A 3000-year culture sequence from Palau, western Micronesia. Asian Perspective 44: 349-380. 
Clark GR, Anderson A, Wright D. 2006. Human colonization of the Palau Islands, Western Micronesia. Journal of Island and Coastal Archaeology 1: 215-232.

Clark G, Petchey F, Winter O, Carson C, O'Day P. 2010. New radiocarbon dates from the Bapot- 1 site in Saipan and Neolithic dispersal by stratified diffusion. Journal of Pacific Archaeology 1(1): 21-35.

Clark G, Szabó K. 2009. The fish bone remains. In The Early Prebistory of Fiji, Clark GR, Anderson AJ (eds). ANU E Press: Canberra; 213-230. Terra Australis 31.

Clark G, Wright D. 2005. On the periphery? Archaeological investigations at Ngelong, Angaur Island, Palau. Micronesica 38(1): 67-91.

Clark G, Wright D. 2007. Reading Pacific pots. In Vastly Ingenious: The archaeology of Pacific material Culture in Honour of Janet M. Davidson, Anderson A, Green K, Leach F (eds). University of Otago Press: Dunedin; 173-190.

Corwin CG, Rogers CL, Elmquist PO. 1956. Military geology of Palau Islands, Caroline Islands. Intelligence Division, Office of the Engineer, Headquarters U.S. Army Far East.

Davidson JM, Fraser K, Leach BF, Sinoto YH. 1999. Prehistoric fishing at Hane, Ua Huka, Marquesas Islands, French Polynesia. New Zealand Journal of Archaeology 21: 5-28.

Dickinson WR, Athens SJ. 2007. Holocene palaeoshorelines and palaeoenvironmental history of Palau: Implications for human settlement. Journal of Island and Coastal Archaeology 2: 175-196.

Fitzpatrick SM. 2003. Early human burials in the western Pacific: evidence for a c. 3000 year old occupation on Palau. Antiquity 77: 719-731.

Fitzpatrick SM, Kataoka O. 2005. Prehistoric fishing in Palau, Micronesia: evidence from the northern Rock Islands. Archaeology in Oceania 40: 1-13.

Fitzpatrick SM, Nelson GC, Clark G. 2008. Small scattered fragments do not a dwarf make: Biological and archaeological data indicate that prehistoric inhabitants of Palau were normal sized. PLoS ONE 3(8): e3015 (1-12).

Golbuu Y, Victor S, Wolanski E, Richmond RH. 2005. The state of coral reef ecosystems of Palau. Available at: http:// ccma.nos.noaa.gov/ecosystems/coralreef/coral_report_2005/ Palau_Ch17_C.pdf [Accessed on 19 February 10].

Gordon EA. 1993. Screen size and differential faunal recovery: A Hawaiian example. Journal of Field Archaeology 20: 453-460.

Intoh M, Ono R. 2006. Reconnaissance archaeological research on Tobi Island, Hatohobei State, Palau. People and Culture in Oceania 22: 53-82.

Johannes RE. 1981. Words of the Lagoon: Fishing and Marine Lore in the Palau district of Micronesia. University of California Press: Berkeley.

Keate G. 1789 An account of the Pelew Islands, situated in the western part of the Pacific Ocean. Composed from the journals and communications of Captain Henry Wilson and some of bis officers, who, in August 1783, were there shipwrecked, in the Antelope, a packet belonging to the Honourable East India company. (3rd edn). Printed for Captain Wilson: London.
Kirch PV, Dye TS. 1979. Ethno-archaeology and the development of Polynesian fishing strategies. Journal of the Polynesian Society 88: 53-76.

Leach BF. 1986. A method for analysis of Pacific island fishbone assemblages and an associated data base management system. Journal of Archaeological Science 13(2): 147159.

Leach BF, Davidson JM. 1977. Fishing methods and seasonality at Paremata (N160/50). New Zealand Archaeological Association Newsletter 20(3): 166-175.

Leach BF, Davidson JM, Horwood M, Ottino, P. 1997. The fishermen of Anapua Rock Shelter, Ua Pou, Marquesas Islands. Asian Perspectives 36(1): 51-66.

Liston J. 2005. An assessment of radiocarbon dates from Palau, western Micronesia. Radiocarbon 47: 295-354.

Liston J. 2009. Cultural chronology of earthworks in Palau, western Micronesia. Archaeology in Oceania 44(2): 56-73.

Loto'ahea T, Sone S. 1995. Age analysis of the shells of the Horses's Hoof Clam, Hippopus bippopus, found on Tongatapu Island. Fisheries Research Bulletin of Tonga 4: 1-6.

Masse WB. 1986. A millennium of fishing in the Palau Islands, Micronesia. In Traditional Fishing in the Pacific: Ethnograpbic and Archaeological Papers from the 15th Pacific Science Congress. Anderson A (ed.). Department of Anthropology, Bernice P. Bishop Museum: Honolulu; 85-117.

Masse WB. 1989. The archaeology and ecology of fishing in the Belau Islands, Micronesia, Part 1 and Part 2. University Microfilms International: Ann Arbor, MI.

Masse WB, Liston J, Carucci J, Athens S. 2006. Evaluating the effects of climate change on environment, resource depletion, and culture in the Palau Islands between AD 1200 and 1600. Quaternary International 151: 106-132.

Masse WB, Snyder D, Gumerman GJ. 1984. Prehistoric and historic settlement in the Palau Islands, Micronesia. New Zealand Journal of Archaeology 6: 107-127.

Nagaoka L. 1994. Differential recovery of Pacific Island fish remains: Evidence from the Moturakau Rockshelter, Aitutaki, Cook Islands. Asian Perspectives 33: 1-17.

Nagaoka L. 2005. Differential recovery of Pacific Island fish remains. Journal of Archaeological Science 32: 941-955.

Nunn PD. 2007. The AD 1300 Event in the Pacific Basin. The Geographical Review 97: 1-23.

O'Day S. 1997. Vertebrate remains. In Compact Road archaeological investigations, Babeldaob Island, Republic of Palau. Historic preservation investigation Phase II. Volume VII: Laboratory Analyses, Synthesis, and Recommendations, Liston J (ed.). International Archaeological Research Institute, Inc.: Honolulu, Hawaii. 106-115.

Ono R. 2003. Prehistoric Austronesian fishing strategies: A tentative comparison between Island Southeast Asia and Lapita Cultural Complex. In Pacific archaeology: Assessments and Prospects. Proceedings of the New Caledonia 2002 Conference, Sand C (ed.). 191-201. Les Cahiers de l'Archéologie en Nouvelle-Calédonie 15. Service des Musees et du Patrimoine: New Caledonia. 
Ono R. 2004. Prehistoric fishing at Bukit Tengkorak rock shelter, east coast of Borneo Island. New Zealand Journal of Archaeology 24: 77-106.

Ono R. 2006. Marine Exploitation and Subsistent Strategies in Celebes Sea: An ethnoarchaeological studies to area studies. Unpublished PbD Thesis, University of Sophia, Tokyo (in Japanese).

Ono R. 2007. Tradition and Modernity in Fishing among the Sama, Eastern Coast of Borneo, Malaysia. Bulletin of the National Museum of Etbnology 31 (4): 497-579 (in Japanese).

Ono R. 2009. Ethnoarchaeology in coral seas. Quarterly of Archaeological Studies 55(4): 175-194 (in Japanese).

Ono R. 2010. Ethnoarchaeology and the early Austronesian fishing strategies in near-shore environments. Journal of the Polynesian Society 119(3): 269-314.

Ono R, Addison D. 2009. Ethnoecology and Tokelauan fishing lore from Atafu atoll, Tokelau. SPC Traditional Marine Resource Management and Knowledge Information Bulletin 26: 3-22.

Ono $\mathrm{R}$, Intoh M. (In press). Island of pelagic fishermen: Temporal change of prehistoric fishing on Fais, Micronesia. Journal of Island and Coastal Archaeology.

Osborne D. 1966. The Archaeology of the Palau Islands. Bernice P. Bishop Museum Bulletin 230. Bishop Museum Press: Honolulu.

Osborne D. 1979. Archaeological test excavations Palau Islands 1968-1969. Micronesica (Suppl. 1): 353.

Petchey F, Clark G. 2010. A marine reservoir correction value $(\Delta \mathrm{R})$ for Palau Islands: An evaluation of extant and new $\Delta \mathrm{R}$ values and their application to archaeological deposits at Ulong. Journal of Island and Coastal Archaeology 5: 236-252.

Reitz EJ, Quitmyer IR, Marrinan RA. 2009. What are we measuring in the zooarchaeological record of prehispanic fishing strategies in the Georgia Bight, USA? Journal of Island and Coastal Archaeology 4(1): 2-36.

Rolett B. 1989. Hanamiai: Changing subsistence and ecology in the prebistory of Tabuata, Marquesas Islands, Frencb Polynesia. University Microfilms: Ann Arbor.

Sachs JP, Sachse D, Smittenberg RH, Zhang Z, Battisti DS, Golubic S. 2009. Southward movement of the Pacific intertropical convergence zone AD 1400-1850. Nature Geoscience 2: 519-525.

Stuiver M, Braziunas TH. 1993. Modeling atmospheric 14C influences and $14 \mathrm{C}$ ages of marine samples to $10000 \mathrm{BC}$. Radiocarbon 35: 137-189.

Stuiver M, Reimer PJ. 1993. Extended 14C data base and revised CALIB 3.0 14C age calibration program. Radiocarbon 35: 215-230.
Snyder DM. 1989. Towards chronometric models for Palauan prebistory: Ceramic attributes. University Microfilms International: Ann Arbor, MI.

Snyder D, Butler BM. 1989. Micronesian resources study. Palau archaeology. Arcbaeology and bistoric preservation in Palau. Micronesian endowment for historic preservation, Republic of Palau and U.S. National Park Service.

Takayama J, Intoh M, Takasugi H. 1980. Archaeological Survey on Kayangel and Angaur in the Palaus. Reports of Pacific Archaeological Survey 7. Tezukayama University: Tokyo.

Takayama J, Takasugi H. 1978. Preliminary Report on the Archaeological Excavation of PAAT-2 in Palau. Historic Preservation Office, U.S. Trust Territory of the Pacific Islands, Saipan.

Taylor JD. 1978. Faunal response to the instability of reef habitats: Pleistocene molluscan assemblages of Aldabra atoll. Palaeontology 21(1): 1-30.

Thomas DH. 1969. Great Basin hunting patterns: A quantitative method for treating faunal remains. American Antiquity 34: 393-401.

Toizumi T. 2007. Analytical problems with identification of fish remains in prehistoric Ryukyu: Influences from differences in screening methods and identified elements used in analysis. In Archaeological Studies on the Cultural Diversity in Southeast Asia and its Neigbbors, Marui M (ed.). Yuzankaku Press: Tokyo; 307-320 (In Japanese).

Vogel Y. 2005. Ika. Unpublished MA Thesis, Department of Anthropology, University of Otago.

Walter R. (ed.). 1998. Fish and fishing. In Anai'o: The Archaeology of a Fourteenth Century Polynesian Community in the Cook Islands. New Zealand Archaeological Association Monograph 22: New Zealand; 64-73.

Welch DJ. 2001. Early upland expansion of Palauan settlement. In Pacific 2000: Proceedings of the Fifth International Conference on Easter Island and the Pacific, Stevenson CM, Lee G, Morin FJ (eds). Easter Island Foundation and Bearsville Press: California; 179-184.

Wickler S. 2002. Terraces and villages: transformation of the cultural landscape in Palau. In Pacific Landscapes: Archaeological Approaches in Oceania, Ladefoged T, Graves M (eds). Easter Island Foundation and Bearsville Press: California; 63-96.

Wright A, Richards AH. 1985. A multispecies fishery associated with coral reefs in Tigak Islands, Papua New Guinea. Asian Marine Biology 2: 69-84.

Wright D. 2005. The Archaeology of Aulong and the colonization of Palau. Unpublished MA Thesis, Department of Archaeology and Anthropology, The Australian National University. 